\title{
Geographical Indications and Designations of Origin linked Agricultural Products: Current Statistics from Turkey ${ }^{\#}$
}

\author{
Didar Ucuncuoglu 1 ,a,* \\ ${ }^{I}$ Department of Food Engineering, Faculty of Engineering, Çanklrı Karatekin University, 18100 Çankırl, Turkey \\ *Corresponding author

\begin{tabular}{|c|c|}
\hline A R T I C L E I N F O & A B S T R A C T \\
\hline $\begin{array}{l}\text { \#This study was presented as an oral } \\
\text { presentation at the } 1^{\text {st }} \text { International } \\
\text { Congress of the Turkish Journal of } \\
\text { Agriculture - Food Science and } \\
\text { Technology (Antalya, TURJAF 2019) } \\
\text { Research Article } \\
\text { Received : 28/11/2019 } \\
\text { Accepted : 04/02/2020 } \\
\text { Keywords: }\end{array}$ & $\begin{array}{l}\text { Geographical indications and designation of origins is an industrial property right describing a } \\
\text { product originated from any region or attributable to any region due to its quality, reputation or other } \\
\text { characteristics. Particularly, the geographical indications (GI) provide information about the raw } \\
\text { material or final products' geographical roots to consumers and characterize the degree of its quality. } \\
\text { Two types of GI were defined: Protected Designations of Origin (PDO) and Protected Geographical } \\
\text { Indication (PGI). On the other hand, the products that cannot be registered as a designation of origin } \\
\text { or geographical indication could be registered as Traditional Speciality Guaranteed (TSG) products } \\
\text { specialty guaranteed if it can be proven that the product is on the traditional market for at least } 30 \\
\text { years. The main goal of this research is to examine Turkey's current status about labelled geographic } \\
\text { agricultural material with a comparative statistic overview. }\end{array}$ \\
\hline
\end{tabular} \\ Keywords:
}

Agriculture

Agricultural economy

Food industry

Geographical Indication

Designations of Origin

didaru@karatekin.edu.tr

(iD)http://orcid.org/0000-0002-2640-5976 |

\section{Introduction}

Food quality is mostly composed of experience qualities (i.e. taste, ripeness, freshness, flavour or aroma) and convenience supplemented by credence qualities (i.e. origin, production method, healthfulness, safety, homogeneity, and environmental impacts). Major quality cues are commonly linked with brand, price, appearance, and the market in which the product is sold. Geographical indications and traditional specialties designations are important instruments of the European Union's product quality policy. The European Commission, as part of its policy on food quality, has adopted schemes where quality labels can be awarded to products fulfilling certain conditions. These schemes are Protected Designation of Origin (PDO) expresses as 'covers agricultural products and foodstuffs which are produced, processed a prepared in a given geographical area using recognised knowhow'; Protected Geographical Indication (PGI) determines as 'covers at least one of the stages of agricultural products and foodstuffs closely linked to the geographical area';
Traditional Speciality Guaranteed (TSG) means as 'highlights traditional character, either in the composition or means of production'. The three labels are shown in Figure 1. The advantage of geographical indications and designations of origin among other industrial property rights is to provide protection for the manufacturer who applies for the registration of geographical indication and designation of origin and also all those people manufacturing under same conditions. Because these origin signatures have some sort of anonymity, a kind of local, regional, country wise generality, the rights provided through such signs cannot be attributed to an individual or individuals. Fruits, vegetables, stones, mine types of any region may be different from those in the other regions or any carpet, rug, fabric, tile, etc. may have a gain attraction for whatsoever is the reason. The use of the name of the region with such products may be perceived by the consumers as their distinctive features from those with similar nature. The consumers may prefer the products sold 
with the name of such regions instead of the other products because they rely on the name of the region. Therefore, many products characterized by their geographical or traditional origin are preferred by consumer segments, indicating that consumers seem to make inferences about origin and traditional ways of production by other, nonregulated forms of branding and market communication. The field is thus potentially open for imitations and watered-down versions of the original products. EU quality labels can have an important function in containing this development, but this is contingent on consumers using these labels in their decision-making. Geographical indications and designations of origin are dimensioned in the manner that they are shaped, packaged, purchased and sold through the traditional knowledge and they are the signs of guarantee evidencing the quality of the product, traditional production method, and geographical origin.

The Republic of Turkey, Ministry of Industry and Technology, Turkish Patent and Trademark Office (TURKPATENT) is the only authorized employment in Turkey for protecting industrial property rights such as patent, utility model, trademark, design, geographic signs, and traditional product names. According to TURKPATENT statistics, in 2000, there were a totally 9 applied and 3 registered geographic signs (PDO and PGI). However, there are 426 applied and 463 registered geographic signs by now (2019). 62.6\% of registration is about PDO and the others are PGI. "Processed or unprocessed fruits and vegetables, and mushrooms" class is the highest percentage of registered geographic signs.

It was aimed in this study to review the literature and authorized websites based on PDO, PGI and TSG application, publication and registration statistics in terms of "processed or unprocessed fruits and vegetables, and mushrooms" agricultural class and to examine it as a useful case summary.
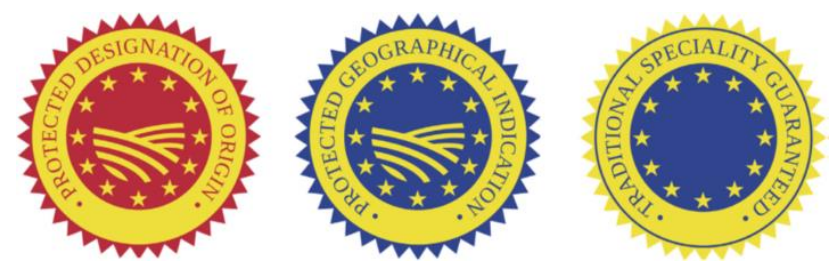

Figure 1. PDO, PGI and TSG label emblems

\section{Materials and Methods}

The methodology includes reviewing the literature and European regulations on the subject, collecting and analysing statistical data as well as examining a short practical case. Therefore, a literature search has been conducted in Web of Science, Science Direct and Google Scholar using combinations of the following keywords: Intellectual and Industrial Property Rights, geographic origin, Protected Designation of Origin, Protected Geographical Indication, Traditional Speciality Guaranteed, Protected Denomination of Origin, certificates of origin, regional certification labels, agricultural raw materials, foodstuffs, quality, quality perception, consumer willingness. Besides, studies commissioned by authorities were identified through EU websites such as DOOR and TURKPATENT.

\section{Results and Discussion}

\section{PDO\&PGI}

It was presented in Figure $2 \mathrm{~A}$ that $65 \%$ of registration linked geographical signs were PDO and $35 \%$ of registration was PGI. It could be seen that agricultural products ("processed or unprocessed fruits and vegetables, and mushrooms" class) had 90\% PDO and 10\% PGI registration (Figure 2B). At the same time, this class contained approximately $40 \%$ of PDO and $4 \%$ of PGI registration (Figure $3 \mathrm{~A}$ and Figure $3 \mathrm{~B}$ ). Those geographic labeling has been heavily applied/published/registered for cotton, olive, grape, onion, bean, rice, nut, peanut, hazelnut, cherry, apricot, banana, tomato, avocado, kiwi, eggplant, pepper, basil, fig, chestnut, mandarin, orange, 'gilaburu', peach, mulberry, tobacco, melon, watermelon, pomegranate, honey, carrot, pear, apple, 'bulgur', saffron, potato, pumpkin, garlic, and artichoke products, in particular.

\section{TSG}

'Çakallı Menemeni' (2019), 'Yoğurt' (2019), 'Türk Lokumu (Turkish Delight)' (2018) and 'Ezo Gelin Çorbası' (2017) are the applied TSG documents to TURKPATENT. There are no registered or published TSG signature linked agricultural products (TURKPATENT, 2019).

\section{International Signatures}

'Geleneksel Türk Ahududu Likörü' (PDO/2011), 'Geleneksel Türk Çilek Likörü’ (PDO/2011), 'Geleneksel Türk Gül Likörü’ (PDO/2008), 'Geleneksel Türk Kayıs1 Likörü' (PDO/2008), 'Geleneksel Türk Vişne Likörü' (PDO/2011), 'Rakı' (PDO/2010), 'Türk Rakısı' (PDO/1997) and 'Türk Tazısı' (PDO/2002) are Turkish International registered geo-labeled products; however, none of them are agricultural final products classified as "processed or unprocessed fruits and vegetables, and mushrooms" (TURKPATENT, 2019).

'Champagne' (PDO/2017), 'Grana Padano' (PDO/2018), 'Hellim/Halloumi' (PDO/2010), 'Parmigiano Reggiano (Parmesan Peyniri)' (PDO/2017), 'Prosciutto Di Parma (Parma Ham/Parma Jambonu)' (PDO/2013) and 'Scotch Whisky (İskoç Viskisi)' (PDO/2011) are the registered international geo-labeled products (TURKPATENT, 2019) to Turkey.

'Malatya Kayısısı' (2017) and 'Aydın İnciri' (2016) are the two PDO signature registered by European Commission (EC). Moreover, 'Giresun Tombul Fındı ğı' (2018), 'Edremit Körfezi Yeşil Çizik Zeytini' (2018), 'Bayramiç Beyazı' (2018), 'Milas Zeytinyağı' (2017), 'Antepfistığı/Antep Fistığı' (2017), 'Taşköprü Sarımsağı' (2017) and 'Aydin Kestanesi' (2015) are the seven PDO signature applied by European Commission (EC).

'Antep Baklavası/Gaziantep Baklavası' (2013) is the only PGI signature registered by European Commission (EC). Moreover, 'Antakya Künefesi' (2019), 'Antep Lahmacunu' (2018), 'Kayseri Mantısı' (2017), 'Kayseri Pastırması' (2017), 'Kayseri Sucuğu' (2017), 'Inegöl Köfte' (2014), 'Afyon Sucuğu' (2012) and 'Afyon Pastırması' (2012) are the eight PGI signature applied by European Commission (DOOR, 2019). 
$\square$ Total registered PDO $\quad$ Total registered PGI

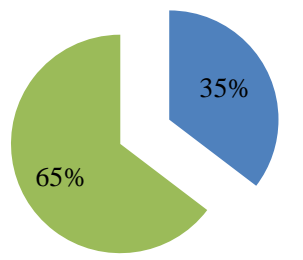

(a)

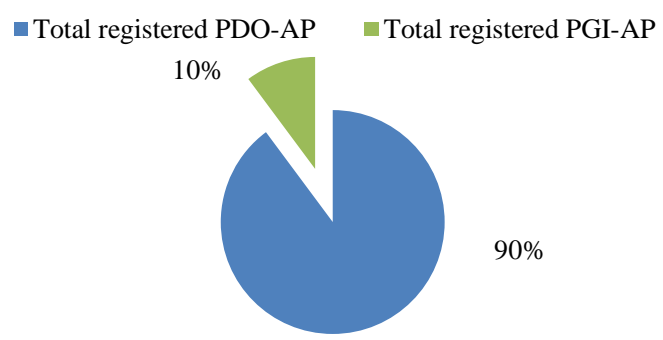

(b)

Figure 2. Registered geographic indications from Turkey (Source: https://www.ci.gov.tr)

PDO: Protected Designations of Origin; PGI: Protected Geographical Indication; PDO-AP: Protected Designations of Origin linked Agricultural Products ("processed or unprocessed fruits and vegetables, and mushrooms"); PGI-AP: Protected Geographical Indication linked Agricultural Products ("processed or unprocessed fruits and vegetables, and mushrooms").

- Total registered PDO $\quad$ Total registered PDO-AP

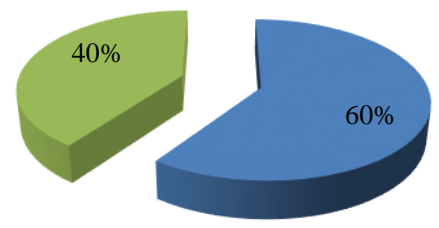

(a)

$\square$ Total registered PGI $\square$ Total registered PGI-AP

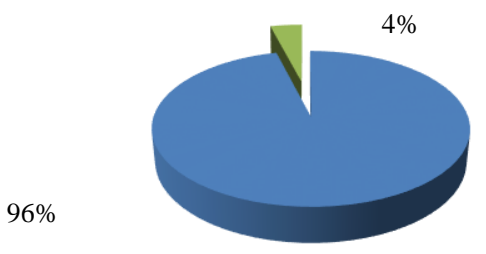

(b)

Figure 3. PDO and PGI percentage of agricultural products from Turkey

PDO: Protected Designations of Origin; PGI: Protected Geographical Indication; PDO-AP: Protected Designations of Origin linked Agricultural Products ("processed or unprocessed fruits and vegetables, and mushrooms"); PGI-AP: Protected Geographical Indication linked Agricultural Products ("processed or unprocessed fruits and vegetables, and mushrooms" class)

\section{Conclusion}

Turkey has 158 registered PDO and 289 registered PGI signature. Besides, 106 of PDO and 12 of PGI signature concerning agricultural final products classified as "processed or unprocessed fruits and vegetables, and mushrooms". On the other hand, there are 217 applied PDO and 202 applied PGI signature, and, 131 of PDO and 25 of PGI linked "processed or unprocessed fruits and vegetables, and mushrooms". It was advocated by European Union legislation that quality guarantee can generate utilities for both producers (i.e. economic performance) and consumers, and improve rural development processes regularly. Therefore, Turkey needs more applications for labeling of rural famous materials such as agricultural raw materials, food products, meals, textile products, etc to raise rural economy.

\section{References}

Dias C, Mendes L, 2018. Protected Designation of Origin (PDO), Protected Geographical Indication (PGI) and Traditional Speciality Guaranteed (TSG): A bibiliometric analysis. Food Research International 103:492-508. http://dx.doi.org/10.1016 /j.foodres.2017.09.059

EC 2019. European Comission, Agriculture and Rural Development, Available from: https://ec.europa.eu/ agriculture/quality/door/list.html [Accessed: 20.11.2019].

Gawron JC, Theuvsen L, 2008. Certification schemes in the European agrifood sector: Overview and opportunities for Central and Eastern Europe. Contributed Paper presented at IAMO Forum.

Gragnani M, 2012. The EU Regulation 1151/2012 on Quality Schemes for Agricultural Products andFoodstuffs. European Food and Feed Law Review, 8:6, 376-385. https://www.jstor.org/stable/24325986

Grunert KG, Achmann K, 2018. Consumer reactions to the use of EU quality labels on food products: A review of the literature. Food Control 59:178-187. http://dx.doi.org/10.1016 /j.foodcont.2015.05.021

Hajdukiewicz A, 2014. European Union agri-food quality schemes for the protection and promotion of geographical indications and traditional specialities: an economic perspective. Folia Horticulturae 26/1: 3-17. http://dx.doi.org /10.2478/fhort-2014-0001

TURKPATENT, 2019. Turkish Patent and Trademark Office, Geographical Signs Portal. Available from: https://www.ci.gov.tr/ [Accessed: 20.11.2019].

Verbeke W, Pieniak Z, Guerrero L, Hersleth M, 2012. Consumers' Awareness and Attitudinal Determinants of European Union Quality Label Use on Traditional Foods. Bio-based and Applied Economics 1(2): 213-229. www.fupress.com/bae 